\title{
DEVELOPMENT OF ANDROID-BASED PENCAK SILAT LEARNING MEDIA FOR HIGH SCHOOL STUDENTS
}

\author{
*Pedomanta Keliat, Mhd Syaleh, Ahmad Al Munawar
}

Correspondence: Faculty of Sport Science, STOK Bina Guna, Medan, Indonesia Email: keliatpedomanta@gmail.com

\begin{abstract}
This research is development research $(R n D)$, where the stages in its implementation are through 4D steps, namely Define, Design, Development, and Dissemination. The data collection instrument used observation, interviews, and the distribution of closed questionnaires to 30 respondents (high school students). Product testing is carried out through the justification of two experts tasked with overseeing the product to be produced. Before the product is tested on respondents, consultation activities with these experts are very important to maintain the direction and steps taken by the original purpose. The experts involved in this research activity are one expert in learning Pencak silat and one expert in learning media. The data analysis used is descriptive, where expert judgment and respondent's assessment will determine the final product. Respondents have assessed this product through the distribution of questionnaires where the score obtained is 53.11 if converted. The resulting product gets the predicate "Eligible." In addition to the assessment using a questionnaire, the researcher also asked for suggestions/input from the respondents for product perfection.
\end{abstract}

\section{Keywords : Pencak Silat, Learning Media}

\section{Introduction}

This research $x_{\text {wilf }}$ produce a final product, namely ancrepticition that contains content in the form of basic techniques of Pencak silat through a $4 \mathrm{D}$ approach, namely Define, Design, Development, and Dissemination. The rationale in this research is to provide easy access to students in learning activities, especially in the subjects of physical education, health, and sports. In addition, the product of this research is expected to provide "positive busyness" to students who are the population that dominates the use of smartphones wherein accessing something they have no control over other than themselves. Hopefully, the product of this research in the form of an application provides a cheerful additional menu for students to spend their time in activities.

This type of research is development research $(\mathrm{RnD})$, where experts are needed who function as validation in product development (Sugiyono, 2016: 28). Research activities started on the 27th of August 2020, involving five research teams, two experts, and one expert in Informatics and Technology (IT). It is planned that this research activity will end in November 2020.

PJKR

https://jurnal.unimed.ac.id/2012/index.php/jpehr 
The design of this study started from a needs analysis in the field in which data was taken from physical education teachers at schools through interview techniques which concluded that it was deemed necessary to have practical and innovative solutions. Furthermore, the researchers carried out modeling with Use Case systems, Activity Diagrams, Sequence Diagrams, Pseudocode, Flowcharts, and System interface design.

\section{Method}

Data analysis was carried out to provide a valid (valid) label on the resulting product. Data analysis will be carried out by two experts who are competent in their fields, namely an expert in learning Pencak silat and an expert in learning media. Through these two experts, the researchers conducted consultations and revisions, which would then be tested on 30 respondents from high school students where students were given a closed questionnaire through the google form service as many as 15 questions that lead to user assessments of the products produced.

From the respondents' answers, it will be converted into a norm where the feasibility of the product will be seen from the user's side. The following table results the respondents' answers.

Table 1. Frequency Distribution of Small Group Trial Results

\begin{tabular}{|l|l|l|l|}
\hline Category & Score & Frequency & Percentage \\
\hline Very Worthy & $75,00<\mathrm{X} \leq 100,00$ & - & - \\
\hline Worthy & $50,00<\mathrm{X} \leq 75,00$ & 17 & $57 \%$ \\
\hline Not feasible & $25,00<\mathrm{X} \leq 50,00$ & 13 & $43 \%$ \\
\hline Very Inappropriate & $25,00<\mathrm{X} \leq 50,00$ & - & - \\
\hline \multicolumn{2}{|l|}{ Total } & 30 & $100 \%$ \\
\hline
\end{tabular}

The datain the table shows a-score that isconverted into an expected value with a range of $0-100$. Students carried out the assessment by filling out a questionnaire on a google form which was distributed from 15 questions regarding the feasibility of the product from the user's point of view. Then the average score was 53.11. With this score, it could be interpreted that this product was said to be feasible to use. In addition to a closed questionnaire, the researcher also provides a suggestion column that is presented for product changes and improvements.

\section{Discussion}

The use of learning media designed aims to provide convenience to students by accessing them via smartphones. To be able to use this learning media (application), first download the application through the Play store. This is in accordance with the rules of learning media stated by Arsyad (2010:7), namely that this learning media is easy to reproduce.

PJKR_

https://jurnal.unimed.ac.id/2012/index.php/jpehr 
The modeling in this study is a Use Case system, Activity Diagram, Sequence Diagram, Pseudocode, Flowchart, and System interface design.

\section{a. Use Case Diagram}

Use Case Modeling is the process of modeling system functions in the context of business events, who initiated them, and how the system responds. Use case (Figure 1.1). The user consists of two, namely Students and Operators, for students to read the modules that have been presented and for operators to process learning modules. The following is a diagram of the application's use case that was built:

Android-Based Pencak Silat Learning Media

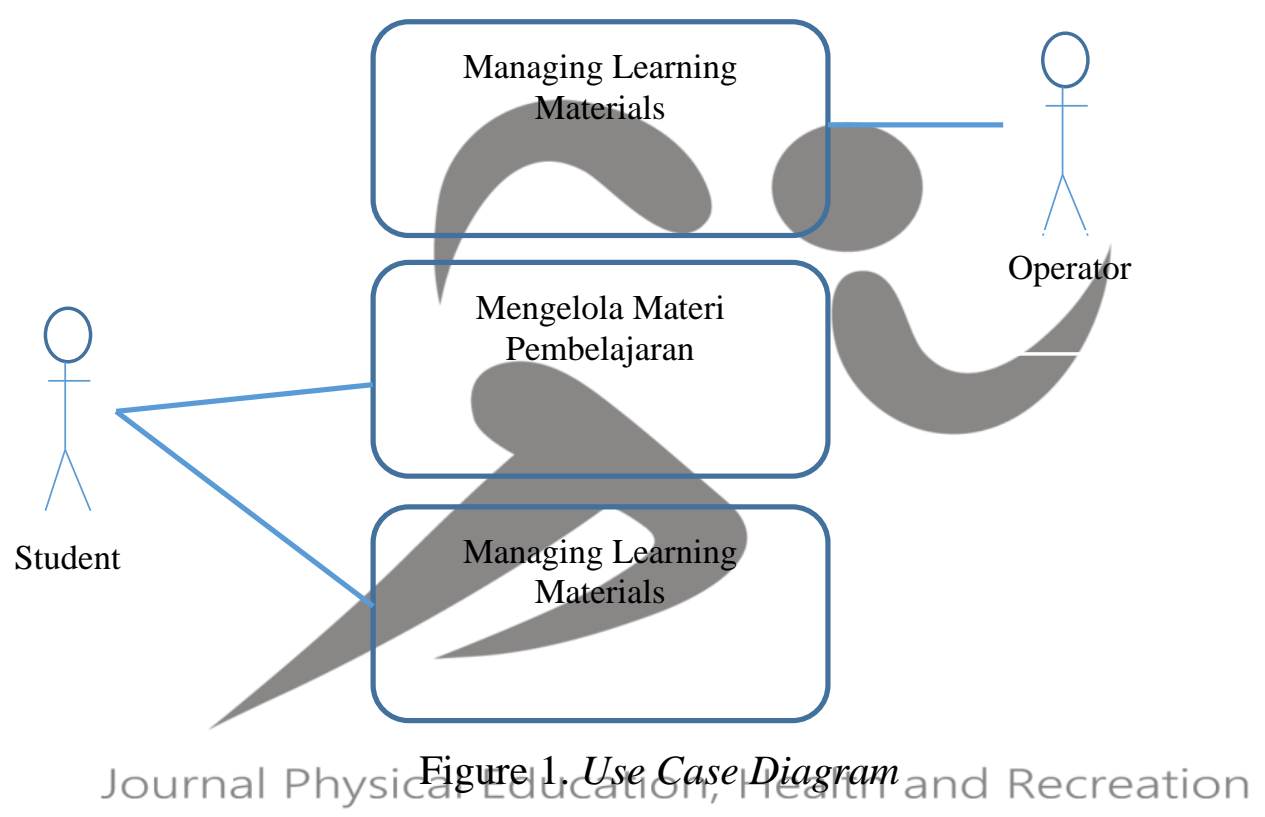

\section{b. Activity Diagram}

Activity Diagram is one of the diagrams in the Unified Modeling Language (UML), which is used to graphically describe the process flow of an object, the steps of a use case, or the logic behavior (method) of an object.

PJKR

https://jurnal.unimed.ac.id/2012/index.php/jpehr 

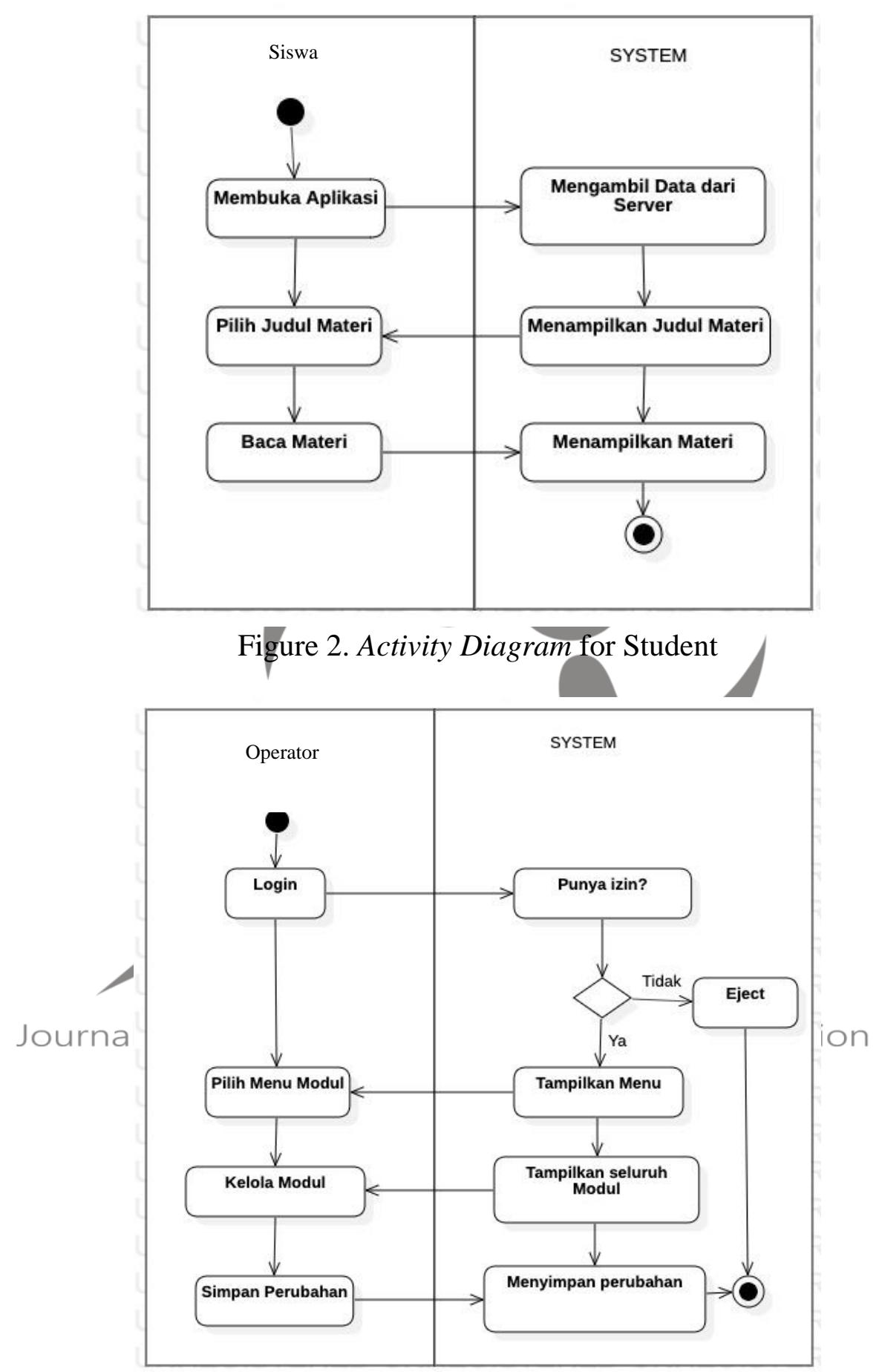

Figure 3. Activity Diagram for Operator

\section{c. Sequence Diagram}

A sequence diagram is a UML (Unified Modeling Language) diagram used to model the logic of a use case by describing the interaction of messages 
between objects in a time series (Figure 4). The following is a Sequence Diagram of Android-based martial arts learning media application for high school students:

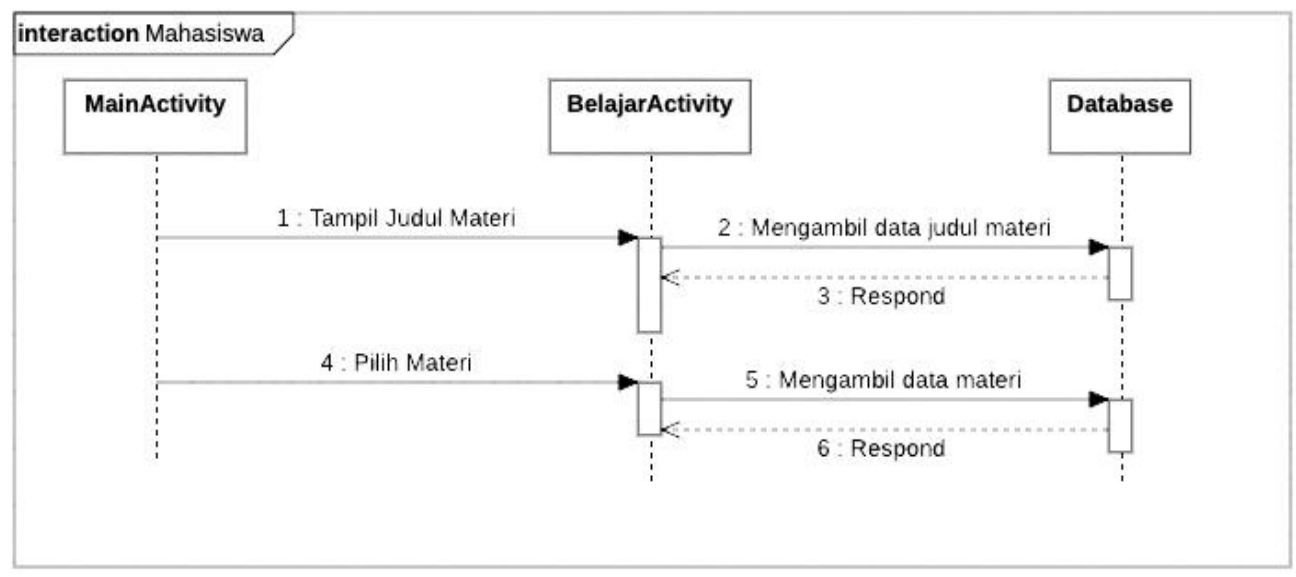

Figure 4. Sequence Diagram

For the design of the application design is divided into two Mobile and Web as follows:

a. Mobile design. It is divided into two main views: the display containing the menu to select the module, and the second display the module's contents.
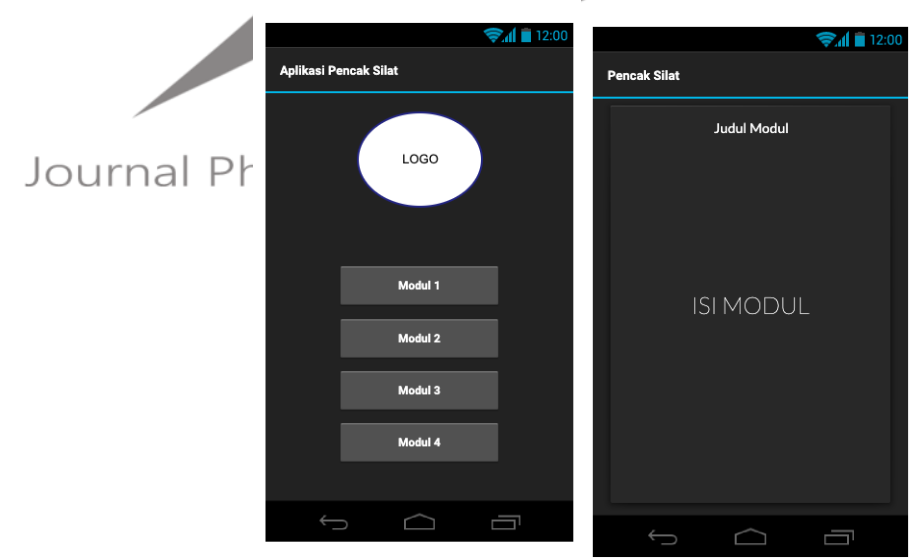

Figure 5. Application Menu Display and Module Contents

b. Desain rancangan web untuk pengolahan modul pembelajaran login bagi operator 

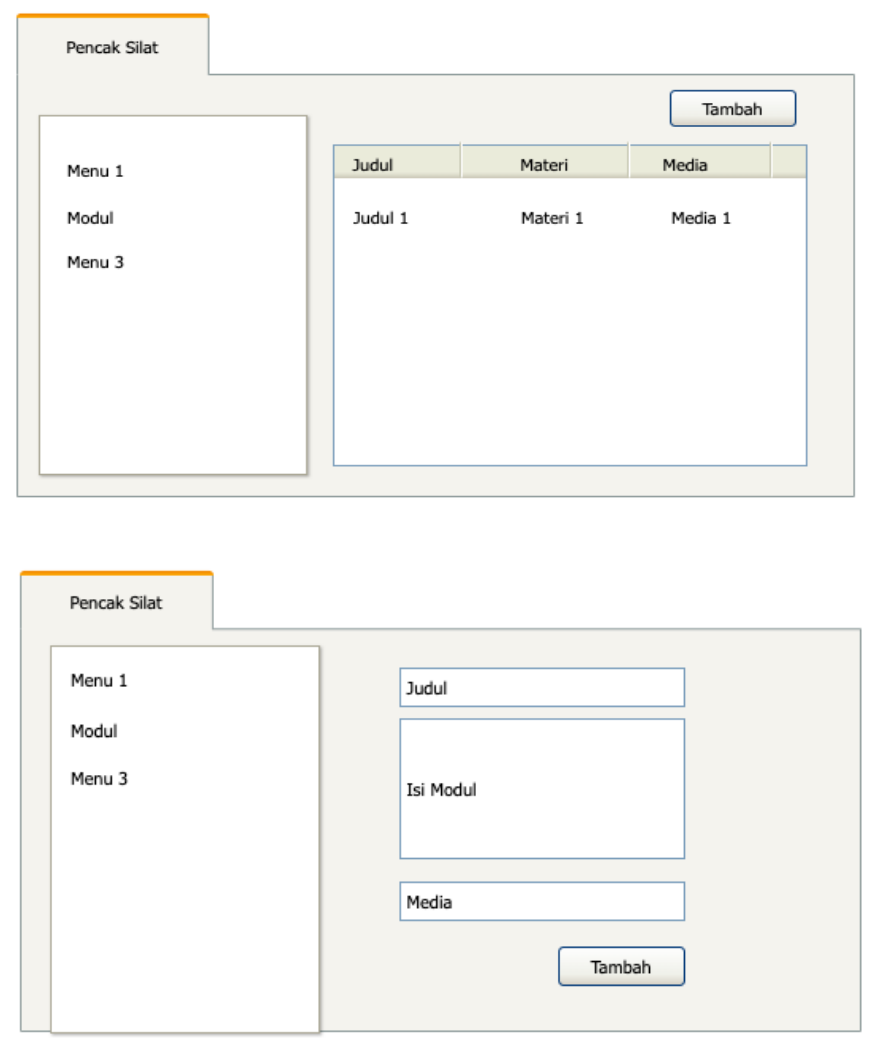

Figure 6. Module Processing Menu and Module Design

The feasibility of using this application was assessed by two experts on learning media and materials. The assessment of the feasibility of the application is based on the ease of access, the comfort of use, and the ease of understanding the contents of the application. Based on the results of "Justification," the expert said that thismediaPwasfeasibletouse.tion, Health and Recreation

Furthermore, after being validated by experts and declared eligible for use, the researchers tested it on 30 respondents at the high school level by providing an assessment questionnaire. Based on the questionnaire distribution given to 30 respondents at the high school student level, a score of 53.11 was obtained, which, if converted, the resulting product received the predicate "Eligible."

The content in the application is the basic technique of Pencak silat, which consists of pairs, stances, kicks, punches, and elbows, all of which are teaching materials studied in Pencak silat subjects. In addition to the questionnaire, the researcher also asked for criticism and suggestions from users regarding appearance, access buttons, and understanding of content. This input is the basis for improvements to the designed learning media.

PJKR_

https://jurnal.unimed.ac.id/2012/index.php/jpehr 


\section{Conclusion}

The results in the study are:

1. Development of media based on the syllabus on physical education subjects, health, and sports in schools with competency standards, students can perform basic techniques of Pencak silat correctly and adequately. The topic of discussion is the basic techniques of Pencak silat, which consist of pairs of stances, stances, punches, kicks, and elbows.

2. The operation of learning media applications can be accessed through the play store by downloading the application first, which makes it easier for students to find information that is not limited by space and time.

3. Based on the feasibility test results conducted by two experts, this application could be used or "Eligible."

4. Furthermore, the feasibility test results are given by the respondent (user) through a questionnaire, giving a score of 53.11. If converted, the resulting product gets the "Eligible" predicate.

\section{References}

Adam, Steffi. Syastra, T.M. 2015. Pemanfaatan Media Pembelajaran Berbasis Teknologi Informasi Bagi Siswa Kelas X Sma Ananda Batam. Batam; Universitas Putera Batam. CBIS Journal Vol.3 No.2, : 78-90

Hamdi, G, Krisnawati. 2011. Membangun Aplikasi Berbasis Android "Pembelajaran Psikotes" Menggunakan App Inventor. Yogyakarta: STMIK AMIKOM. Jurnal DASI Vol.12 No.4. Desember 2011: 37-41

Karo-kari IR, Rohani. 2018. Manfaat Media Dalam Pembelajaran. FITK. UIN SU Medan.Jurnal AXIOM Vol.VII. No.1 Januari-Juni 2018 : 91-96

Keliat, Pedomanta. 2015. Pencak Silat. Medan: Sekolah Tinggi Olahraga dan Kesehatan Bina Guna

Murtiwiyati, Lauren, G. 2013 . Rancang Bángun Aplikasi Pembelajaran Budaya Indonesia Untuk Anak Sekolah Dasar Berbasis Android. Jurnal Ilmiah Komputasi. Vol 12 No 2:2.

Pratama, Yudha Toni. 2017 Pembelajaran Seni Pencak Silat Terhadap Peningkatan Kebugaran Jasmani Anak Tunagrahita Sedang. FKIP. Universitas Sultan Ageng Tirtayasa. Jurnal Pendidikan dan Kajian Seni Vol.2 No.2. Oktober 2017:165-184

Resiani, Ni Kadek, Anak Agung G.A, Nyoman Jampel. 2015. Pengembangan Game edukasi Interaktif Pada Mata Pelajaran IPS Siswa Kelas VII Semester Genap di SMP N 7 Singaraja Tahun Ajaran 2014/2015. eJournal Edutech Universitas Pendidikan Ganesha Jurusan Teknologi Pendidikan, Vol: 3 No: 1.

Satyaputra, Alfa, Aritonang, M.A. 2016. Let's Build Your Android Apps With Android Studio. Jakarta : PT Elex Media Komputindo

Sugiyono. 2016. Penelitian dan Pengembangan. Jakarta. Cipta Pustaka

PJKR

https://jurnal.unimed.ac.id/2012/index.php/jpehr 